Zeszyty Naukowe Szkoły Głównej Gospodarstwa Wiejskiego w Warszawie

Problemy Rolnictwa Światowego tom 18 (XXXIII), zeszyt 4, 2018: 323-332

DOI: 10.22630/PRS.2018.18.4.122

Elwira Laskowska $^{1}$, Anna Twardowska ${ }^{2}$

Szkoła Główna Gospodarstwa Wiejskiego w Warszawie

\title{
Teoretyczne i praktyczne aspekty wyceny prawa użytkowania wieczystego gruntu
}

\section{The Theoretical and Practical Aspects of Appraisal of the Perpetual Usufruct Right to Land}

\begin{abstract}
Synopsis. Celem artykułu jest porównanie zasad określania wartości gruntu w zależności od celu wyceny związanego z użytkowaniem wieczystym oraz wskazanie głównych problemów związanych $\mathrm{z}$ wyceną tego prawa. Zakres artykułu obejmuje problematykę wyceny dla następujących celów: oddania nieruchomości w użytkowanie wieczyste, aktualizacji opłat $\mathrm{z}$ tytułu użytkowania wieczystego, przekształcenia prawa użytkowania wieczystego w prawo własności oraz obrotu wtórnego użytkowaniem wieczystym. Do zrealizowania celu wykonano przegląd literatury i przepisów prawa oraz przeprowadzono ankietę wśród osób posiadających uprawnienia w zakresie szacowania nieruchomości. Uzyskane wyniki badań potwierdzają niedoskonałość przepisów regulujących zasady wyceny związanej z prawem użytkowania wieczystego, skutkujących odmiennym poziomem wartości w zależności od celu szacowania. Również w opinii rzeczoznawców majątkowych taka wycena przysparza trudności.
\end{abstract}

Slowa kluczowe: nieruchomość, użytkowanie wieczyste, wycena

\begin{abstract}
The main purpose of this study is the comparison of the rules in order to specify the appraisal of the land according to the aim of the appraisal connected with the perpetual usufruct. Another purpose is to indicate main problems related to the appraisal of this right. The area of the study covers the rules and the problems of the appraisal of this law for the following aims: establishment of the perpetual usufruct, update the charges for the perpetual usufruct, the transformation the perpetual usufruct into ownership and the secondary sale. The analysis of the source literature and the regulations were applied and the survey was conducted among the persons who are authorized to appraise the real estate in order to achieve the purpose of the study. The obtained results confirm the imperfection of the provisions regulating the appraisal principles related to the right of perpetual usufruct. This results in a different level of value depending on the purpose of the estimation. Also in the property appraisers opinion, the appraisal connected with the perpetual usufruct poses difficulties.
\end{abstract}

Keywords: real estate, perpetual usufruct, appraisal

JEL Classification: R14, R52

\footnotetext{
${ }^{1}$ dr inż., Katedra Ekonomiki Rolnictwa i Międzynarodowych Stosunków Gospodarczych SGGW w Warszawie, ul. Nowoursynowska 166,02-787 Warszawa, e-mail: elwira_laskowska@sggw.pl; https://orcid.org/0000-0002-4577-4283

${ }^{2}$ mgr inż., Katedra Ekonomiki Rolnictwa i Międzynarodowych Stosunków Gospodarczych SGGW w Warszawie, ul. Nowoursynowska 166,02-787 Warszawa, e-mail: anna_twardowska@sggw.pl; https://orcid.org/0000-0002-6079-3044
} 


\section{Wstęp}

Majątek publiczny, który jest we władaniu Skarbu Państwa oraz jednostek samorządu terytorialnego, może być wykorzystywany przez te organy w różny sposób. Przepisy prawa, w szczególności ustawa z 1997 roku o gospodarce nieruchomościami, przewiduje szereg form gospodarowania nieruchomościami wchodzącymi w skład tego majątku. Jedną z nich jest prawo użytkowania wieczystego.

Instytucja użytkowania wieczystego ma w Polsce długą tradycję i wpisała się w katalog form prawnych gospodarowania nieruchomościami publicznymi. Użytkowanie wieczyste jest charakterystyczne dla polskiego porządku prawnego, jego konstrukcja jest unikalna na tle praw obowiązujących w innych państwach. Użytkowanie wieczyste zostało wprowadzone do polskiego systemu prawnego w latach sześćdziesiątych ubiegłego wieku, jednak mimo znaczących zmian, jakie zaszły od tego czasu w kraju, istota i zakres użytkowania wieczystego nie uległy znaczącym modyfikacjom. Jest to przesłanką do wielu kontrowersji powstających wokół tego prawa. Mimo, że popularność tej formy gospodarowania nieruchomościami systematycznie maleje, to wciąż duża część gruntów publicznych jest objęta użytkowaniem wieczystym.

W związku z tym, iż instytucja użytkowania wieczystego dotyczy mienia publicznego, przepisy prawa wskazują na obligatoryjną obecność rzeczoznawcy majątkowego na wszystkich etapach trwania tego prawa, począwszy od jego ustanowienia, aż po wygaśnięcie. $Z$ tego powodu w polskim prawodawstwie zostały szczegółowo uregulowane sposoby i zasady wyceny nieruchomości będącej przedmiotem prawa użytkowania wieczystego.

Celem niniejszego artykułu jest porównanie zasad określania wartości gruntu w zależności od celu wyceny związanego z użytkowaniem wieczystym oraz wskazanie głównych problemów w związku $\mathrm{z}$ taką wyceną. Zastosowano następujące metody badawcze: analizę opisową i przyczynowo - skutkową metodę porównawczą oraz badanie ankietowe. Dla potrzeb realizacji celu wykorzystano następujące źródła: przepisy prawa, literaturę przedmiotu oraz opinie rzeczoznawców majątkowych.

\section{Użytkowanie wieczyste w polskim systemie prawnym}

Użytkowanie wieczyste jest prawnorzeczową formą długoterminowego korzystania z gruntów Skarbu Państwa bądź jednostek samorządu terytorialnego. W polskim prawodawstwie użytkowanie wieczyste zostało uformowane jako prawo rzeczowe, umiejscowione pomiędzy prawem własności - najsilniejszym prawem rzeczowym, a ograniczonymi prawami rzeczowymi (Ignatowicz i Stefaniuk, 2012).

Zgodnie z art. 233 Kodeksu cywilnego, użytkowanie wieczyste zostało zdefiniowane w następujący sposób: „w granicach, określonych przez ustawy i zasady wspólżycia społecznego oraz przez umowę o oddanie gruntu Skarbu Państwa lub gruntu należacego do jednostek samorzqdu terytorialnego badź ich zwiqzków $w$ użytkowanie wieczyste, użytkownik może korzystać z gruntu z wytaczeniem innych osób. W tych samych granicach użytkownik wieczysty może swoim prawem rozporzadzać” (Kodeks cywilny, 1964). Z przytoczonej definicji wynika, iż użytkownikowi wieczystemu przysługują dwa podstawowe uprawnienia, charakterystyczne również dla prawa własności: uprawnienie do korzystania z nieruchomości oraz do rozporządzania swoim prawem. 
Prawo użytkowania wieczystego jest prawem odpłatnym. W momencie ustanowienia prawa użytkowania wieczystego istnieje konieczność zapłaty tzw. opłaty pierwszej, wynoszącej od 15 do 25\% wartości gruntu (Ustawa o gospodarce..., 1997, art. 72 ust. 2). Ponadto użytkownik wieczysty jest zobowiązany $\mathrm{w}$ czasie trwania tego prawa do uiszczania opłat rocznych (Kodeks cywilny, 1964, art. 238). Stawki procentowe opłat rocznych kształtują się od 0,3 do $3 \% \mathrm{w}$ zależności od celu, na jaki grunt został oddany w użytkowanie wieczyste (Ustawa o gospodarce..., 1997, art. 72 ust. 3). Należy przy tym zauważyć iż mimo, że stawka opłaty rocznej w okresie trwania użytkowania wieczystego nie podlega zmianie (o ile nie zmieniono sposobu korzystania $\mathrm{z}$ nieruchomości), to użytkownicy wieczyści nie mają pewności co do wysokości bieżących kosztów wynikających z wykonywania użytkowania wieczystego, bowiem wartość gruntu może ulec zmianie, co z kolei jest przyczyną aktualizacji wysokości opłaty rocznej. Przesłankami, które najczęściej decydują o zmianie wartości nieruchomości są przede wszystkim: zmiany cen na lokalnych rynkach nieruchomości, uchwalenie lub zmiana miejscowego planu zagospodarowania przestrzennego bądź zmiany $\mathrm{w}$ otoczeniu nieruchomości, w szczególności na skutek realizacji inwestycji infrastrukturalnych (Dydenko, 2012).

Podstawą określenia wysokości opłat oraz ich aktualizacji, oprócz stawek procentowych, jest wartość nieruchomości gruntowej oszacowana przez rzeczoznawce majątkowego.

\section{Zasady wyceny nieruchomości związanej z użytkowaniem wieczystym w zależności od celu szacowania}

Wycena nieruchomości związanej $\mathrm{z}$ prawem użytkowania wieczystego jest obligatoryjna w następujących sytuacjach (Klusek, 2006):

- Skarb Państwa lub jednostka samorządu terytorialnego planują oddać nieruchomość w użytkowanie wieczyste,

- przeprowadza się proces aktualizacji opłat rocznych z tytułu użytkowania wieczystego,

- prawo użytkowania wieczystego wygasa, na skutek upływu okresu ustalonego w umowie o oddanie nieruchomości w użytkowanie wieczyste lub też, jeżeli umowa zostanie rozwiązana przed upływem tego okresu,

- właściciel nieruchomości (Skarb Państwa lub jednostka samorządu terytorialnego) sprzedaje nieruchomość użytkownikowi wieczystemu lub następuje przekształcenie prawa użytkowania wieczystego w prawo własności nieruchomości.

Oprócz wyżej wymienionych celów, fakultatywnie dokonuje się wyceny gruntu jako prawa użytkowania wieczystego przykładowo dla potrzeb: ustalenia ceny sprzedaży na rynku wtórnym tego prawa, rachunkowości, wniesienia tego prawa jako aportu do spółki i innych.

Szczegółowe zasady wyceny, według których dokonuje się określenia wartości nieruchomości związanej z prawem użytkowania wieczystego, regulują m.in. przepisy rozporządzenia Rady Ministrów z dnia 21 września 2004 r. w sprawie wyceny nieruchomości i sporządzania operatu szacunkowego. Zasady te, w zależności od celu wyceny, przedstawiono na rysunku 1 oraz opisano poniżej. 


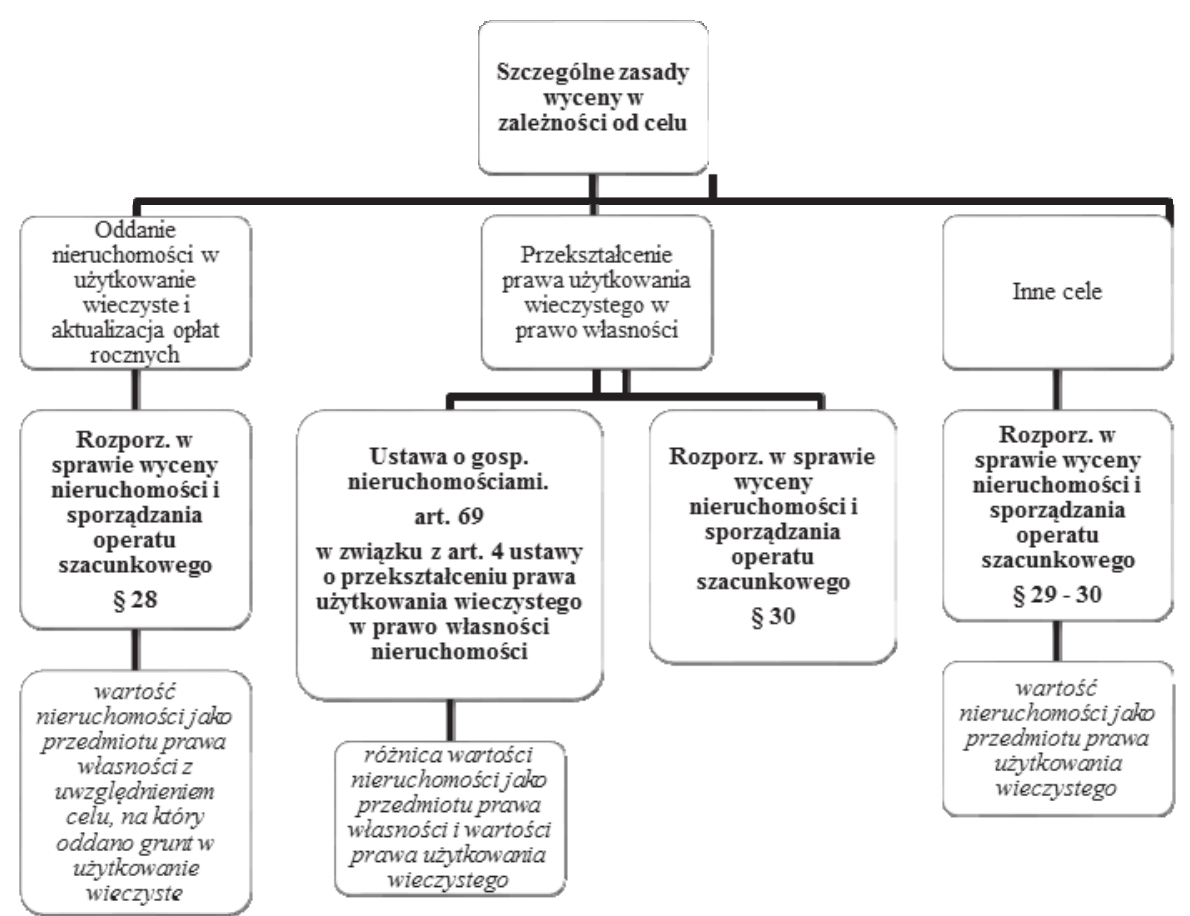

Rys. 1. Schemat zasad wyceny związanej z prawem użytkowania wieczystego w zależności od celu szacowania

Fig. 1. Scheme of valuation principles related to the right of perpetual usufruct depending on the purpose

Źródło: opracowanie własne.

\section{Oddanie gruntu w użytkowanie wieczyste oraz aktualizacja opłat rocznych}

Wartość nieruchomości jest określana według stanu nieruchomości oraz cen na datę oddania nieruchomości w użytkowanie wieczyste albo na dzień aktualizacji opłat $\mathrm{z}$ tytułu użytkowania wieczystego, z uwzględnieniem celu, na jaki użytkowanie wieczyste zostało ustanowione (Rozporządzenie..., 2004, §28 ust. 5). Użyte określenie „stan nieruchomości” należy rozumieć jako „stan zagospodarowania, stan prawny, stan techniczno-użytkowy, stopień wyposażenia w urządzenia infrastruktury technicznej, a także stan otoczenia nieruchomości, w tym wielkość, charakter i stopień zurbanizowania miejscowości, w której nieruchomość jest położona" (Ustawa o gospodarce..., 1997, art. 4 pkt. 17).

Kolejna zasada stanowi, że przy określaniu wartości nieruchomości gruntowej niezabudowanej na potrzeby ustalenia jej ceny oddania w użytkowanie wieczyste lub aktualizacji opłat rocznych wykorzystuje się ceny transakcyjne sprzedaży nieruchomości niezabudowanych jako przedmiotu prawa własności (Rozporządzenie..., 2004, §28 ust. 1). Jednak, rozporządzenie $\mathrm{w}$ sprawie wyceny nieruchomości i sporządzania operatu szacunkowego wskazuje na trzy możliwe przypadki, które może spotkać rzeczoznawca majątkowy wyceniając nieruchomość dla powyższych celów:

- na rynku właściwym dla wycenianej nieruchomości istnieje obrót nieruchomościami niezabudowanymi jako przedmiotu prawa własności. W takiej sytuacji do porównań 
przyjmuje się zbiór cen transakcyjnych tych nieruchomości, jako podstawy do wyceny w podejściu porównawczym;

- na rynku nieruchomości odpowiednim ze względu na lokalizację przedmiotowej nieruchomości nie ma transakcji sprzedaży nieruchomości niezabudowanych będących przedmiotem prawa własności, lecz dokonano transakcji sprzedaży takich nieruchomości jako przedmiotu użytkowania wieczystego. W takim przypadku wartość rynkową nieruchomości jako przedmiotu prawa własności należy określić na podstawie relacji między cenami nieruchomości jako przedmiotu prawa własności, a cenami nieruchomości jako przedmiotu prawa użytkowania wieczystego, które zostały uzyskane na innych, porównywalnych rynkach nieruchomości;

- na lokalnym rynku brak jest transakcji własności nieruchomości gruntowych niezabudowanych oraz nie ma możliwości wskazania relacji pomiędzy wartością prawa własności, a wartością prawa użytkowania wieczystego z rynków porównywalnych. W takiej sytuacji wartość prawa własności można określić obliczając iloraz wartości nieruchomości będącej przedmiotem prawa użytkowania wieczystego oraz współczynnika korygującego.

Jeżeli nieruchomość gruntowa oddawana w użytkowanie wieczyste jest zabudowana, to wówczas należy określić wartość całej nieruchomości, jako przedmiotu prawa własności. Następnie z określonej wartości należy wyodrębnić wartość następujących elementów gruntu - który zostanie oddany w użytkowanie wieczyste oraz budynków lub ich części oraz innych urządzeń - które staną się lub stanowią własność użytkownika wieczystego (Rozporządzenie..., 2004, §28 ust.3).

\section{Wygaśnięcie prawa użytkowania wieczystego}

Zgodnie z artykułem 33 ustawy o gospodarce nieruchomościami, w przypadku wygaśnięcia użytkowania wieczystego na skutek upływu okresu ustalonego w umowie albo na skutek rozwiązania umowy przed upływem tego okresu, użytkownikowi wieczystemu przysługuje wynagrodzenie za wzniesione przez niego lub nabyte na własność budynki i inne urządzenia. Wynagrodzenie powinno być równe wartości tych budynków i urządzeń określonej na dzień wygaśnięcia prawa użytkowania wieczystego. Należy przy tym zauważyć, że za budynki i inne urządzenia wzniesione wbrew postanowieniom umowy wynagrodzenie nie przysługuje.

W powyższych sytuacjach wycenie podlegają więc jedynie części składowe gruntu, których wartość określa się jako wartość rynkowa, a jeżeli ze względu na rodzaj nieruchomości nie można określić wartości rynkowej, określa się wartość odtworzeniową (Rozporząazzenie..., 2004, § 33).

\section{Przekształcenie prawa użytkowania wieczystego w prawo własności}

Zgodnie z treścią ustawy o przekształceniu prawa użytkowania wieczystego w prawo własności nieruchomości, takie przekształcenie jest odpłatne (Ustawa o przekształceniu..., 2005, art. 4 ust. 1). W zakresie zasad ustalenia wysokości opłaty z tytułu przekształcenia, powyższa ustawa deleguje do art. 67 ust. 3a i art. 69 ustawy o gospodarce nieruchomościami, z których wynika, że podstawą do wyznaczenia takiej opłaty jest cena nieruchomości określona na podstawie jej wartości. Ponadto, na poczet ceny nieruchomości gruntowej sprzedawanej jej użytkownikowi wieczystemu zalicza się kwotę równą wartości prawa użytkowania wieczystego tej nieruchomości, którą należy obliczyć jako iloczyn wartości nieruchomości gruntowej niezabudowanej będącej przedmiotem prawa własności 
i współczynnika korygującego. Współczynnik korygujący oblicza się zgodnie ze wzorem (Rozporządzenie..., 2004, § 29.1):

$W_{h}=\left(1-\frac{S_{r}}{E}\right) \times\left(\frac{t}{T}\right)+0,25 \times \frac{T-t}{T}$

gdzie:

$W_{k}$ - współczynnik korygujący;

$S_{r}-$ stawka procentowa opłaty rocznej nie większa niż 3\%;

$t$ - liczba lat niewykorzystanego okresu użytkowania wieczystego;

$T$ - liczba lat, na które ustanowiono użytkowanie wieczyste;

$R$ - przeciętna stopa kapitalizacji ustalana na podstawie badania rynku nieruchomości

przez rzeczoznawcę majątkowego, nie mniejsza jednak niż 0,09 i nie większa niż 0,12 .

Przedstawiony powyżej sposób postępowania jest obowiązujący w procesie przekształcania prawa użytkowania wieczystego $\mathrm{w}$ prawo własności nieruchomości. Jednak ustawa o przekształceniu prawa użytkowania wieczystego $\mathrm{w}$ prawo własności nieruchomości przewiduje w szczególnym przypadku odmienny sposób ustalenia wartości nieruchomości jako prawa własności. A mianowicie, jeśli nie wcześniej niż w okresie ostatnich dwóch lat przed dniem złożenia wniosku o przekształcenie prawa użytkowania wieczystego w prawo własności nieruchomości była dokonana aktualizacja opłaty rocznej z tytułu użytkowania wieczystego, to wówczas dla ustalenia opłaty z tytułu przekształcenia prawa użytkowania wieczystego w prawo własności nieruchomości, przyjmuje się wartość nieruchomości określoną dla celów tej aktualizacji (Ustawa o przekształceniu..., 2005, art. 4 ust. 13). Powyższy przepis nie jest bezsporny. Jak wskazano poprzednio, wyceny nieruchomości w celu aktualizacji opłat rocznych dokonuje się z uwzględnieniem celu, na jaki nieruchomość została oddana w użytkowanie wieczyste, natomiast wyceny dla potrzeb przekształcenia prawa użytkowania wieczystego $\mathrm{w}$ prawo własności dokonuje się biorąc pod uwagę przeznaczenie wycenianej nieruchomości w dokumentach planistycznych. Jeżeli cel oddania gruntu w użytkowanie wieczyste jest odmienny od aktualnego przeznaczenia dopuszczenie możliwości wykorzystania operatu sporządzonego dla celów aktualizacji wydaje się w takim wypadku watpliwe.

Również odmienny sposób ustalenia opłaty z tytułu przekształcenia wprowadza ustawa z dnia 20 lipca 2018 r. o przekształceniu prawa użytkowania wieczystego gruntów zabudowanych na cele mieszkaniowe w prawo własności tych gruntów. Z mocy tej ustawy prawo użytkowania wieczystego gruntów pod budynkami mieszkalnymi jednorodzinnymi oraz budynkami mieszkalnymi wielorodzinnymi, w których co najmniej połowę liczby lokali stanowią lokale mieszkalne, zostanie przekształcone w prawo własności z dniem wejścia w życie ustawy tj. 1 stycznia 2019 r. Opłata z tytułu przekształcenia będzie wynosiła 20. krotność opłaty rocznej z tytułu użytkowania wieczystego. Z uwagi na to, że określona w powyższy sposób opłata nie jest ustalana w oparciu w wartość praw do gruntu, nie będzie wykonywana dla tego celu wycena przez rzeczoznawcę majątkowego.

\section{Wtórny obrót prawem użytkowania wieczystego i inne cele}

Wartość nieruchomości będącej w użytkowaniu wieczystym określa się dla pozostałych celów, to znaczy m.in. dla potrzeb sprzedaży prawa użytkowania wieczystego przez jej użytkownika wieczystego innemu podmiotowi, dla potrzeb podatkowych, w celach odszkodowawczych, określenia wartości nakładów, przy określaniu wartości 
nieruchomości gruntowej jako przedmiotu prawa użytkowania wieczystego, wnoszonej do spółki w formie wkładu niepieniężnego (aportu) i inne. W tych przypadkach oszacowanie wartości nieruchomości następuje na podstawie cen transakcyjnych nieruchomości gruntowych niezabudowanych będących przedmiotem użytkowania wieczystego, z uwzględnieniem wysokości stawek procentowych opłat rocznych i niewykorzystanego okresu trwania prawa użytkowania wieczystego (Rozporządzenie..., 2004, § 29.3).

\section{Problematyka wyceny dla celów związanych z użytkowaniem wieczystym w opinii rzeczoznawców majątkowych}

W celu pozyskania opinii na temat praktycznych aspektów wyceny, przeprowadzono badanie ankietowe skierowane wyłącznie do osób posiadających uprawnienia zawodowe w zakresie szacowania nieruchomości. Otrzymano 59 poprawnie wypełnionych formularzy. Badanie zostało przeprowadzone w maju 2016 roku.

Jako „nieruchomość związaną z prawem użytkowania wieczystego” należało, na potrzeby badania, rozumieć wycenę nieruchomości dla następujących celów: oddanie nieruchomości w użytkowanie wieczyste, aktualizację opłat $\mathrm{z}$ tytułu użytkowania wieczystego, przekształcenie prawa użytkowania wieczystego $\mathrm{w}$ prawo własności oraz obrót wtórny prawem użytkowania wieczystego.

W wyniku przeprowadzonego badania stwierdzono, że zdecydowana większość rzeczoznawców (97\% ankietowanych) sporządzało wycenę nieruchomości związanej z prawem użytkowania wieczystego gruntu.

Według ankietowanych, w zakresie wyceny nieruchomości związanych z prawem użytkowania wieczystego, najczęściej są one przedmiotem szacowania dla celów aktualizacji opłat rocznych (średnio $42 \%$ wycen) oraz obrotu wtórnego (średnio 29,7\%) (rys, 2). W odniesieniu do celu jakim jest oddanie nieruchomości w użytkowanie wieczyste, ponad $70 \%$ ankietowanych nie wykonywała operatów szacunkowych dla tego celu. Może to wynikać z faktu, iż użytkowanie wieczyste jest coraz rzadziej ustanawianą formą gospodarowania nieruchomościami publicznymi.

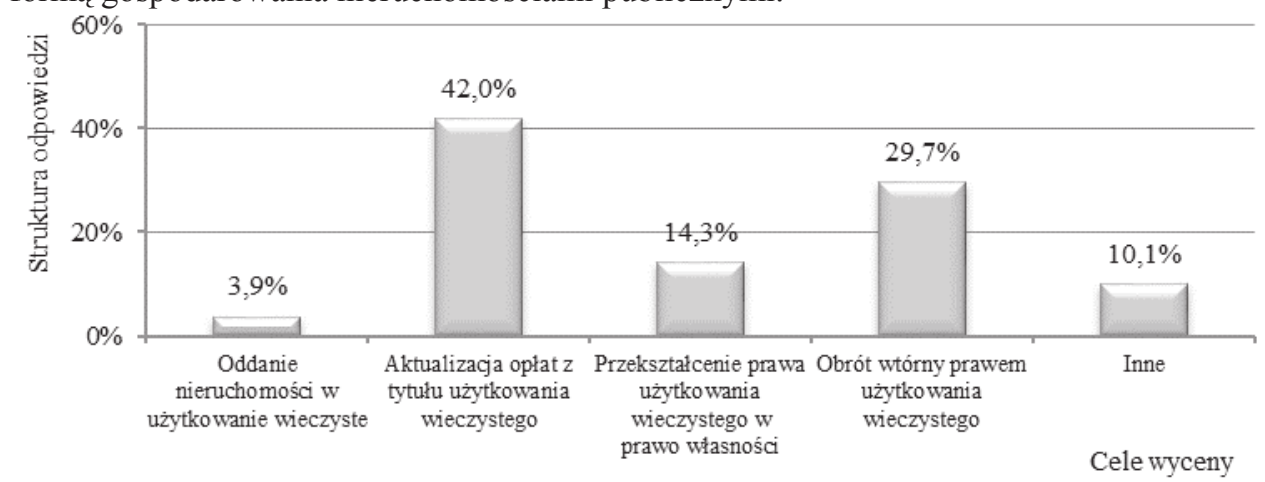

Rys. 2. Udział wycen $\mathrm{w}$ zależności od celu szacowania $\mathrm{w}$ ogólnej liczbie wycen związanych $\mathrm{z}$ prawem użytkowania wieczystego

Fig. 2. The share of valuations depending on the purpose of the estimation in the total number of valuations related to the right of perpetual usufruct

Źródło: opracowanie własne na podstawie wyników badań ankietowych. 
Wyniki badania ankietowego potwierdziły także spotykane przez rzeczoznawców trudności związane z wyceną dla celów związanych z użytkowaniem wieczystym. Jako największy problem wskazano brak możliwości ustalenia z rynku relacji pomiędzy prawem własności a prawem użytkowania wieczystego (średnia ocena 4,33 w skali 0-5, przy czym ocena 0 wskazywała na brak trudności). Kolejnym problemem jest brak transakcji prawem użytkowania wieczystego na lokalnym rynku. Ankietowani zwrócili też uwagę na niedostatecznie precyzyjne określenie sposobu wyceny w przepisach prawa (rys. 3).

Rzeczoznawcy zostali również poproszeni o ocenę przydatności wzoru zamieszczonego w $§ 29$ ust. 3 rozporządzenia w sprawie wyceny nieruchomości i sporządzania operatu szacunkowego, dotyczącego ustalenia relacji pomiędzy prawami własności i użytkowania wieczystego. Pomimo tego, iż większość respondentów dosyć dobrze oceniła określenie zasad wyceny prawa użytkowania wieczystego w przepisach prawa, to jedynie $29 \%$ respondentów uznało, iż wskazany wzór jest prawidłowy. Zdecydowana większość, bo prawie 3/4 rzeczoznawców uważa, że wzór ten wymaga poprawy. Najczęstszymi komentarzami były stwierdzenia, że wzór nie odzwierciedla sytuacji na rynku oraz, że nie odpowiada rzeczywistości. Rzeczoznawcy wskazywali również, że wykorzystanie wzoru zaniża wartość prawa użytkowania wieczystego, która powinna być na poziomie ok. $80 \%$ wartości prawa własności. Podnoszono również kwestie, że zgodnie ze wzorem, im więcej wykorzystano już prawa użytkowania wieczystego, tym jego wartość jest większa, co nie jest kwestią bezsporną. Ankietowani stwierdzali również, że wzór powinien zostać poprawiony przede wszystkim w zakresie stopy kapitalizacji oraz, że aktualnie konstrukcja wzoru nie jest logiczna.

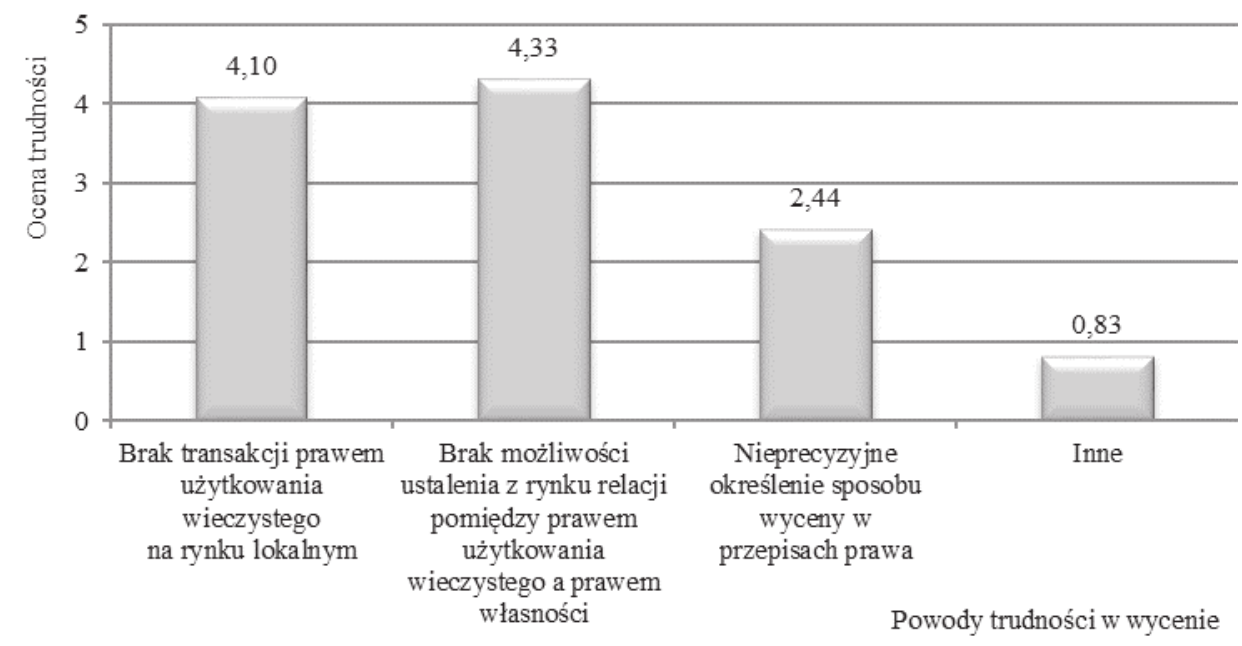

Rys. 3. Powody i ocena trudności w wycenie nieruchomości związanej z prawem użytkowania wieczystego (Ocena w skali 0-5, przy czym 0 - brak trudności)

Fig. 3. Reasons and assessment of difficulty in property valuation related to perpetual usufruct right (Score on a scale of $0-5$, with 0 - no difficulty)

Źródło: opracowanie własne na podstawie wyników badań ankietowych.

$\mathrm{Na}$ pytanie odnoszące się do możliwości wykorzystania operatów szacunkowych wykonanych dla celów aktualizacji na potrzeby przekształcenia prawa użytkowania 
wieczystego w prawo własności nieruchomości w ciagu dwóch lat od daty jego sporządzania (zgodnie z artykułem 4 ust. 13 ustawy z dnia 29 lipca 2005 r. o przekształceniu prawa użytkowania wieczystego w prawo własności nieruchomości), większość respondentów opowiedziała się za taką możliwością. Jednak blisko $40 \%$ ankietowanych rzeczoznawców wskazało, że powyższa regulacja może wywołać negatywne konsekwencje. W uzasadnieniu takiego stanowiska respondenci wskazywali na fakt, iż okres dwóch lat jest to zbyt długi czas, aby móc wykorzystać tę samą wartość, oraz że skoro regułą jest, że operat może być wykorzystywany przez okres 12 miesięcy, to nie ma uzasadnienia, aby w tym przypadku zastosować wyjątek od tej zasady. Kolejnym argumentem podnoszonym przez rzeczoznawców było, iż dla celów aktualizacji opłat z tytułu użytkowania wieczystego uwzględnia się cel, na jaki ustanowiono użytkowanie wieczyste, a cel ten może się istotnie różnić od przeznaczenia nieruchomości w dokumentach planistycznych, co z kolei może być przyczyną różnic w oszacowanej wartości nieruchomości.

Z wypowiedzi respondentów wynika, iż część rzeczoznawców zauważa niekonsekwencje przepisów prawnych w zakresie zasad wyceny prawa użytkowania wieczystego. Przedstawione przez rzeczoznawców argumenty potwierdzają wcześniej postawioną tezę, iż operat szacunkowy wykonany dla potrzeb aktualizacji nie zawsze może być wykorzystany w procedurze przekształcenia prawa użytkowania wieczystego w prawo własności nieruchomości, pomimo iż przepisy prawne dopuszczają taką możliwość.

\section{Podsumowanie}

Prawo użytkowania wieczystego charakterystyczne dla polskiego systemu prawnego wpisało się w polską rzeczywistość. Istota i zakres tego prawa są szczegółowo unormowane w przepisach. Prawo użytkowania wieczystego jest również instytucją, na którą szczególną uwagę powinni zwrócić rzeczoznawcy majątkowi ze względu na fakt, iż są zobligowani do uczestnictwa w większości etapów trwania tego prawa.

Wycena nieruchomości związanych z użytkowaniem wieczystym jest stosunkowo szczegółowo unormowana przepisami prawa, przy czym determinującym sposób wyceny jest cel, dla którego wycena jest sporządzana. W przypadku oddawania nieruchomości w użytkowanie wieczyste oraz aktualizacji opłat rocznych, wyceny nieruchomości dokonuje się jako prawa własności, natomiast w przypadku innych celów m.in. odszkodowawczych czy podatkowych wartość nieruchomości określa się jako prawo użytkowania wieczystego. Jeszcze inne przepisy odnoszą się do wyceny $\mathrm{w}$ związku $\mathrm{z}$ przekształceniem prawa użytkowania wieczystego w prawo własności nieruchomości - rzeczoznawca majątkowy winien dokonać wyceny jako prawa własności i jako prawa użytkowania wieczystego.

W wyniku przeprowadzonych analiz oraz badania ankietowego stwierdzono niedoskonałość przepisów regulujących zasady wyceny dla celów związanych z użytkowaniem wieczystym. W opinii rzeczoznawców majątkowych nieruchomość związana z prawem użytkowania wieczystego, pomimo ścisłych regulacji prawnych dotyczących zasad wyceny, przysparza wielu trudności w procesie szacowania wartości nieruchomości. Niektóre przepisy, w szczególności odnoszące się do wyceny nieruchomości w przypadku przekształcenia prawa użytkowania wieczystego w prawo własności, odbiegają od ogólnie przyjętych reguł szacowania nieruchomości i mogą przyczynić się do zafałszowania rzeczywistej wartości nieruchomości oraz niekorzystnego, dla jednej ze stron, naliczenia opłaty z tytułu przekształcenia. 


\section{Literatura}

Dydenko, J. (red.) (2012). Szacowanie nieruchomości. Rzeczoznawstwo majątkowe (Property appraisal. Property valuation). Wyd. Wolters Kluwer SA, Warszawa.

Ignatowicz, J., Stefaniuk, K. (2012). Prawo rzeczowe (Property law). Wyd. LexisNexis, Warszawa.

Klusek, T. (2006). Wycena nieruchomości na potrzeby gmin - zasady i procedury (Property appraisal for the counties - rules and procedures). ZN SGGW Ekonomika i Organizacja Gospodarki Żywnościowej, 61, 117-130.

Rozporządzenie Rady Ministrów z dnia 21 września 2004 r. w sprawie wyceny nieruchomości i sporządzania operatu szacunkowego. Dz. U. z 2004 r. Nr 207, poz. 2109 z późn. zm.

Ustawa z dnia 23 kwietnia 1964 r. Kodeks cywilny. Tekst jedn. Dz.U. z 2018 r. poz. 1025.

Ustawa z dnia 21 sierpnia 1997 r. o gospodarce nieruchomościami. Tekst jedn. Dz.U. z 2018 r. poz. 121

Ustawa z dnia 29 lipca 2005 r. o przekształceniu prawa użytkowania wieczystego w prawo własności nieruchomości. Tekst jedn. Dz.U. z 2012 r. poz. 83.

Ustawa z dnia 20 lipca 2018 r. o przekształceniu prawa użytkowania wieczystego gruntów zabudowanych na cele mieszkaniowe w prawo własności tych gruntów. Dz. U. z 2018 r. poz. 1716.

Załęczna, M. (2014). Prawo użytkowania wieczystego w kontekście sporów o aktualizację opłaty rocznej (Perpetual usufruct in the context of annual fees updating dispute). Zeszyty Nankowe Uniwersytetu Szczecińskiego. Studia i Prace Wydziatu Nauk Ekonomicznych i Zarzadzania, 36(1), 475-488.

Do cytowania / For citation:

Laskowska E., Twardowska A. (2018). Teoretyczne i praktyczne aspekty wyceny prawa użytkowania wieczystego gruntu. Problemy Rolnictwa Światowego, 18(4), 323-332;

DOI: $10.22630 /$ PRS.2018.18.4.122

Laskowska E., Twardowska A. (2018). The Theoretical and Practical Aspects of Appraisal of the Perpetual Usufruct Right to Land (in Polish). Problems of World Agriculture, 18(4), 323-332;

DOI: 10.22630/PRS.2018.18.4.122 